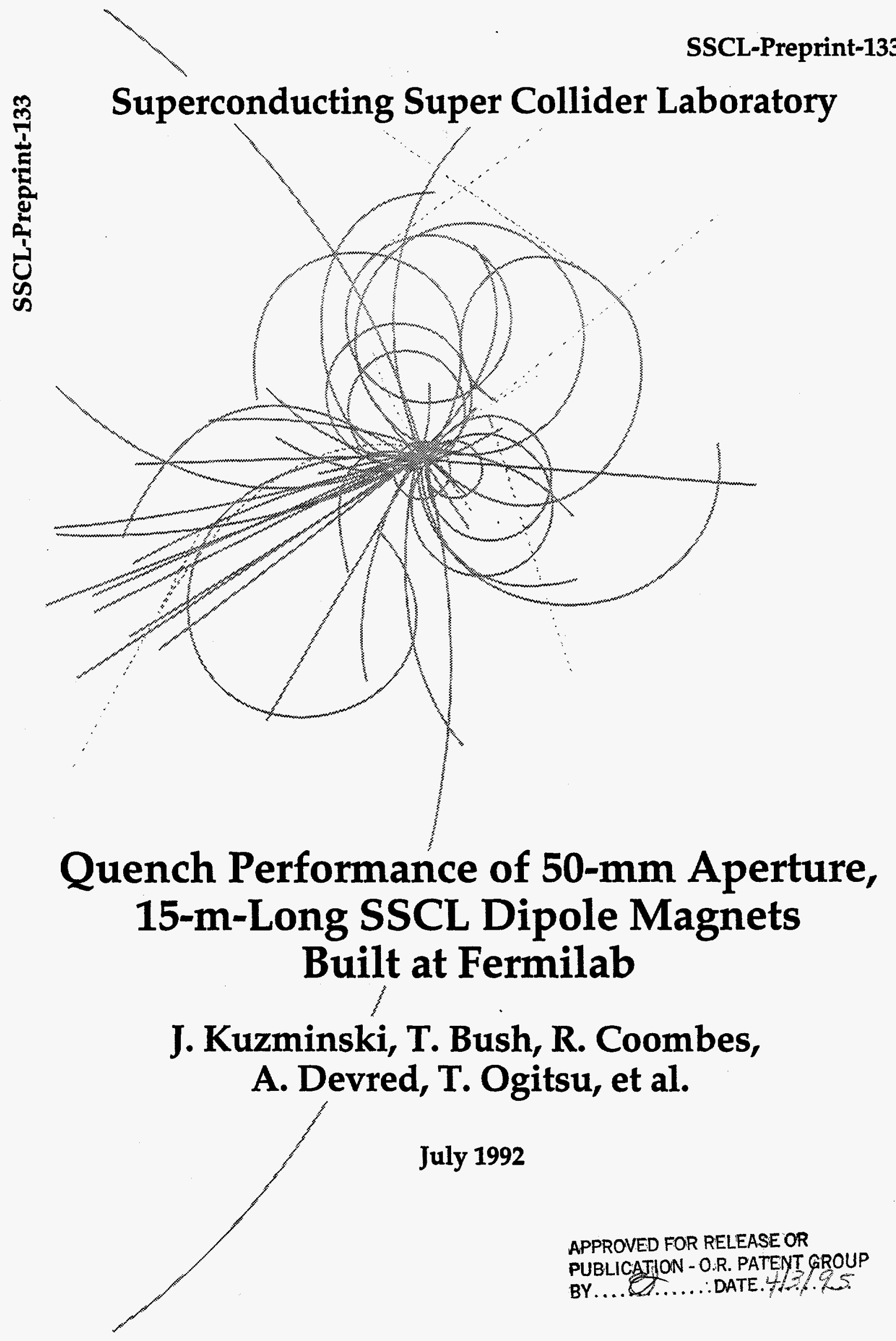




\title{
Quench Performance of 50-mm Aperture, 15-m-Long SSCL Dipole Magnets Built at Fermilab
}

\author{
J. Kuzminski, T. Bush, R. Coombes, \\ A. Devred, T. Ogitsu, et al. \\ Superconducting Super Collider Laboratory ${ }^{\dagger}$ \\ 2550 Beckleymeade Ave. \\ Dallas, TX 75237
}

July 1992

\section{DISCLAIMER}

This report was prepared as an account of work sponsored by an agency of the United States Government. Neither the United States Government nor any agency thereof, nor any of their employees, makes any warranty, express or implied, or assumes any legal liability or responsibility for the accuracy, completeness, or usefulness of any information, apparatus, product, or process disclosed, or represents that its use would not infringe privately owned rights. Reference herein to any specific commercial product, process, or service by trade name, trademark, manufacturer, or otherwise does not necessarily constitute or imply its endorsement, recommendation, or favoring by the United States Government or any agency thereof. The views and opinions of authors expressed herein do not necessarily state or reflect those of the United States Government or any agency thereof.

†Operated by the Universities Research Association, Inc., for the U.S. Department of Energy under Contract No. DE-AC35-89ER40486. 


\section{DISCLAIMER}

Portions of this document may be illegible in electronic image products. Images are produced from the best available original document. 


\title{
Quench Performance of $50-\mathrm{mm}$ Aperture, 15-m-Long SSC Dipole Magnets Built at Fermilab
}

\author{
J. Kuzminski, T. Bush, R. Coombes, A. Devred, J. DiMarco, C. Goodzeit, M. Puglisi, \\ P. Sanger, R. Schermer, J. C. Tompkins, Y. Yus, and H. Zheng \\ SSC Laberatory, 2550 Beckleymeade Avenue, Dallas, TX 75237 USA.
}

T. Ogitsu

SSC Laboratory and KEK, National Laboratory for Gigh Energy Physics, d-1 Ot:o. Tsuluba-shi, Ibaraki-ken 305, Japan
R. Bossert, J. Carson, S. W. Delchamps, S. Gourlay, R. Hanft, W. Koska, M. Kuchnir, M. J. Lamm, P. Mantsch, P. O. Mazur, D. Ortis, J. Ozelis, E. G. Pewitt. T. Peterson, J. Strait, and M. Wakef Fermi Nalional Accelerator Laboralory, Batavla, Il 60510 USA

\begin{abstract}
The quench performance, ranp pate dependence, and moclunical behavior of ter tull-length, SO-mm-aperture, SSC dipolo magnets built at Fermilab are discussed Cold tasting of these mazaets thow that the queneh platesu estabtished at $4.35 \mathrm{~K}$ exeeeds the design value by mose then 10\%, virtually without training.
\end{abstract}

\section{Introduction}

During the past yoar, substuntial progress has bcen achieved in the design and manufacture of full-scale, $50-\mathrm{mm}$ aperture, SSC superconducting dipoie magnets. At Ferrullab, a series of thireen such magnets, designed jointly by Fermilab, Brookhaven National Laboralory (BNL), and the SSC Laboratory, have been built osing the Fermilab full-length tooling; ten have been successfully cold lested to dale. Soven of these dipole magnets, designated for the Accelertor System String Test (ASST) being carried out in Dallas, wero assembled at Fermillab by Gencral Dynamics personnel At BNL a similar program was carried out resulting in a series of seven full-Iength SSC dipole magnets built and cold tested, five of which were assembled by Westinghouse personnel. In this paper we present the cold performance of ten supercondueting dipole magnets bullt and testod at Fermilab. The magnetic field quatify of these magnets is discussed in another report to this conference [1].

\section{Magnet Construction and Instrumentation}

The design of the full-length, 50-mm-aperture SSC dipole magnets has been previously described [2-4]; here we note only the main features. The magretic field is generated by a two layer, $\cos (\theta)$ type coil clamped by stainless steel collars. The collars serve to position the conductor as spectited by the magnetic tesign and to restmin conductor motion under excitation. As th the 40-mm-aperture dipoles. the upper and lower collars are locked together by tupered

This wosk was sopported by the U.S. Department of Energy. lseys and left-right pairs of collars are spol welded to provide greater horizontal stlffness. No pole shims are used, and required prestress is achicved by controlling the molded coil size.

In the Fcrmilab design, a vertically split yoke is employed 10 provide mechanical support to the collass near the horizontal mid-planc and thus to limit deflections under Lorentz force. The $4.95 \mathrm{~mm}$ thich, $340 \mathrm{~mm}$ O.D. stainless steel shell, made from two half-cylinders weided at the vertical parting plane of the yoke, serves as helium containment vessel and is a structure clamping together the two halves of the vertically split yoke. The coil ends have cument blocks, defined by machined $G 10$ spacers, that match those of the two-dimensional cross section. The Inner-outer coil splices are made outside the coil at the lead end. The coil ends and splices are clamped by a collet assembly consigting of a 4-pioce G10 insulator with a tapered outer surface and in abuminum outer cylinder. An aluminum ead cap is walded ovar tho out-boand end of the collet assembly. To provide axial resiraint under excitation, a 38-mm thick and plate is welded to each end of the cold mass strell and the collared coil is preloaded axially against these plates by mcans of four set sercws at each end.

The cable is insulated with the conventional Kapton plus epoxy-Impregnated fiberghass tape in magnets DCA311-319. In the last four magnets (DCA320-323) allernative insulation schemes were employed using all-Kaplon or allApical insulation coaled with 3M cpoxy or Cyorad adhesive respectively (to increase resistance to conductor motion).

The inner coil of each magnet is instrumented with 53 voltage tups located in the six urrns nearest the poles. These voleage taps allow for a quench origin determination with the resolution of a few em for quenches oceurring in the instrumeried iums.

All magnets are equipped with two collar packs instrumented with beam-type strain gauge transducers for azimuthal coil stress measurements (5). These packs are located at positions corresponding to the minimum and maximum of inner coll size. Becausc of the reproducibility achieved with the full-length curing/molding press, these locations were the same in all magnets. In addition, wach 
magnet has one assembly of load cells, mounted on the nonlead end of the magnet to measure the forces between the coil and the end plaic during excitation, and gauges on the cold mass shell.

\section{Experimental Procedure}

The magnet cold lesting was carricd out at the Fermilab Magnet Tost Facility at nomina! temperatures of $4.35 \mathrm{~K}$. $3.85 \mathrm{~K}$ and $3.50 \mathrm{~K}$. The mass flow of supercritieal helium at $4 \mathrm{~atm}$ was $-50 \mathrm{~g} / \mathrm{s}$.

The generic iest sequence calls for unrestricted cool down (i.e. without restriction on the temperature difference between the helium inlet and outlet ends of the magnet) and includes two cest cycles. scparated by warm-up to room temperature. Both testing cycles started at $T=4.35 \mathrm{~K}$ with a strain gavge run. In such a tun the magnet was ramped up to $6500 \mathrm{~A}$ and down to $0 \mathrm{~A}$ at ramp rate of $16 \mathrm{~A} / \mathrm{s}$ in roughly equal steps of $I^{2}$, and data werc collected at euch step. This was followed by a strain gauge run to quench. Bceause of the significant dependenee of the current at quench on samp rate (see Sect. 4.2), lower samp rates were used for currents greater than 5900 A. Additional remps to quench at $4.35 \mathrm{~K}$ followed to establish a quench current plateau. During the first testing cycle, investigations of the ramp rate (dJ/at) dependence of the quench current werc then performed at $4.35 \mathrm{~K}$. During the second testing cycle, after re-establishing a quench plateau at $4.35 \mathrm{~K}$, odditional rests at $3.85 \mathrm{~K}$ and $3.50 \mathrm{~K}$ were performed to delermlne quench performance at these temperalures. Strain gaute ramps 10 currents $100 \mathrm{~A}$ below I ptateau were taiken at each test iemperature. In addition, AC loss measurements were performed $214.35 \mathrm{~K}$ for most of the magnets.

\section{Test results and discussion}

\subsection{Spontaneous quesches}

Figure 1 shows the spontaneous quench performance of the len magnels lested to date - ordered in the sequence as they were tested. Magnels DCA313-DCA319, assembled by GD personacl, are those being used in the string test: DCA312 is the "technology transfer" magnet. Almost all quenches displayed in this plot occurred at a ramp rate $54 \mathrm{~A} / \mathrm{s}$ except for the first five quenches observed in DCA311 (or as noled). The horizonmal dashed line shows the design SSC operaling current of 6600 A (corresponding to 6.7 $\mathrm{T}$. All tested magnets excesded the SSC operating current on the first or second quench and wexe within $100 \mathrm{~A}$ of condector limit on the subsequent quench. Flucturions in the platcau current resuli from variation in the temperalure at quench. There are four quenches below the SSC operating current (magnets DCA $313,314,316$, and 317). In three of the four C2ses (DCA 313, 314, and 317) the quenches originated at the boundary of the coller end clamp and the collared part of coll, near the pole end key. This part, originally designed as a single piece. was made of two picoes to lacilitate assembly. It is believed that the quenches resulted from movement of these picces inio a tinal stable location. This minor construction flaw was later corsected. The fourth low current quench (the first quench in DCA316) occursed in the uninstrumented portion of the coil (tum $0-13$ ) at a ramp rate of $16 \mathrm{~A} / \mathrm{s}$. The cause of this quench is unkrown but its location may indicate that both ramp ratc dependeuke and tsaining are involved.

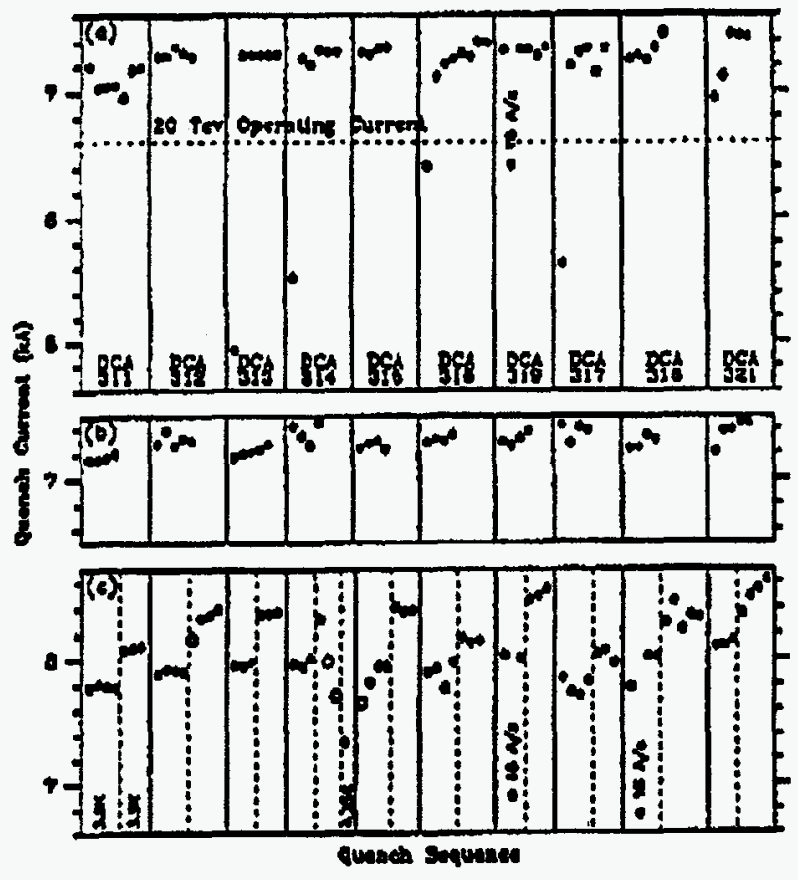

Figure 1. Spontaocous quench performance on the firt (a) and tecond (b) cooldown at $4.35 \mathrm{~K}$, and on the second cooldown at $3.45 \mathrm{~K}$ and $3.50 \mathrm{~K}(\mathrm{c})$. Closed (open) cireles indiente quenches originating bo the inser (outer eoii).

During the second testing cycle no quenches below openting current were observed in any of the magnets. At the lower temperatures, a few magnets exhibited a mild training (one or two quenches) before resehing a plateau in quench currest. A1 $350 \mathrm{~K}$, DCA314 showed degradation in quench performance: it returned however to is previous plalcav curreat when retested at $4.35 \mathrm{~K}$.

\subsection{Quenches at higher ramp rate}

Early in the test progran it was recognized that all magnets exhibit rather significant dependance of quench curnent on ramp rale. Figure 2 summarizes the quench current vs. ramp rate data for the tested magnets. Despite magnet to magnet variations, 2 distinctive behavior is apparent: the curves displaying mmp rate dependence for magncts DCA311. 316, 317, 318, 319. and 321 have a concave shape, in contrast to the convex curves for magnets DCA312-315. The cause of differences in ramp rate dependence between the two groups is not cumently known, but may be kelatod to differences in strand-to-strand resistance within the cable. It is worthwhile to noto that magnets DCA312-315 were all made using superconducting wire supplied by IOC. All other magnels were made using wire 
either from Supercon (DCA311, 321) or Ox[ord (DCA316, 318 , and 319). The only exception is DCA317, which uses IGC wire but whose slope of quench current vs. ramp rate is drematically smaller than in the aher magnets. The cable of DCA317 is from the same billet and would appear to differ from the others made with IGC cablc oniy in thal the cured coils of this magnct were awailing magnet reassembly for more than 6 woeks.

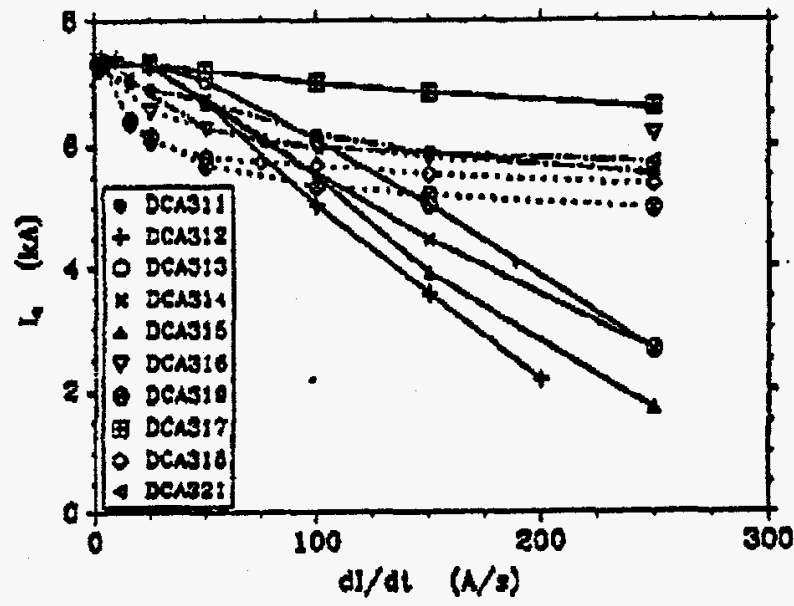

Figre 2. Ranp rate (di/dt) depandunce of quench current.

Though the overall ramp rale dependence does not aftect the collider operation at $4 \mathrm{~A} / \mathrm{s}$, it is a polential problem for faster cycling synchrotrons such as the High Encrgy Booster.

\section{Mechanical behavior}

The azimuthal inner coil stress, averaged over the four quadrants, as a function of $\mathrm{I}^{2}$, is shown in Figure 3 for all tosted magnets.

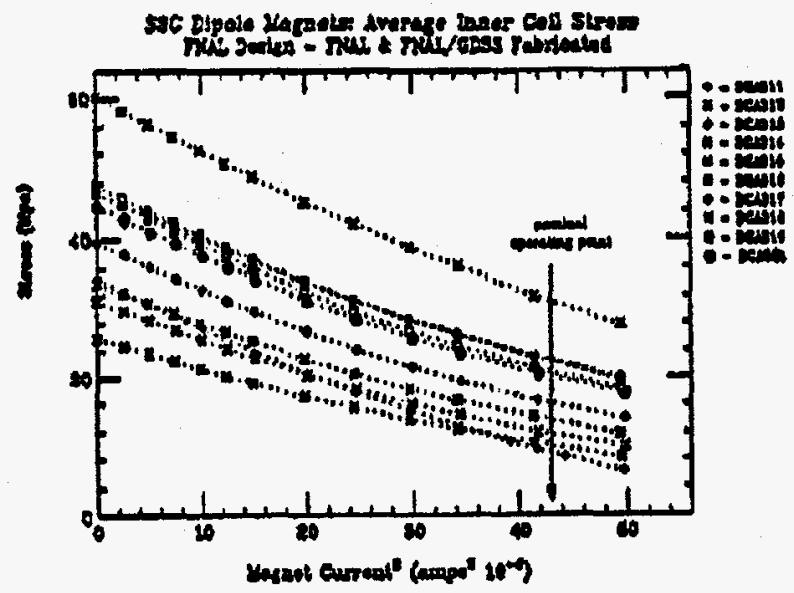

Figure 3. Azimuthal coil stress as a function of $I^{2}$ for all tesled magnetu. Data taken at $4.35 \mathrm{~K}$ during the first thenral cyole.
The average strcss loss between 0 and $6500 \mathrm{~A}$ is about $20 \mathrm{MP}_{2}$ The stress is essentially linear with $\mathrm{l}^{2}$, (i.e. with force during excitation) and the prestress is still posilive even at the highest eutrent at which strain gauge data were taken $(8100 \mathrm{~A})$. In the all $50 \mathrm{~mm}$ magnets tested to date. there is no indication of inner coil unloading [6]. This is in conerast with $40-\mathrm{mm}$-aperture magnets of the DC series [7].

\section{Summary and concluslons}

Thittecn full size, 50-mm-apcrture SSC R\&D magnets have boen built at Fermilab. following the baseline design. The spontaneous quench perfomance of all ten magnets rested to date is substantially better that in the previous $40 \mathrm{~mm}$ protolypes [8]. The quench current was above 99\% of the conductor limit on the first or second quench in all magnets. The significant quench currest dependence on samp raic observed in these magnels is nol well understood at present and is being investigaled further.

\section{Acknowledgements}

We are grateful to the Fermilab and the SSC Labomitory design team and the Fermilab and General Dynamics production staff for their excollent work during this project. We also wish to thank the staff of the Fermilab Magnet Test Facility for their dedication and support of the rest program there.

\section{Reforences}

1 Pernaneal addressi Institute of Elcetrical Engineering. Beijing 100080, Chise

1 Oa leave from KEK, Japar. Present address: SSC Laboratory

[1] J. Strait et al., "Magnetic Field Measurements of FullLength $50 \mathrm{~mm}$ Apertuse SSC Dipolo Magnels at Fermilab", presented at the XVth International Confortnce on High Energy Accoleralors, Hambusg, Germany, July 20-24, 1992.

(2) I. Srait I \&l, Mechanical Dexign of the 2D Crous-Section of uie SSC Collider Dipole Magnets", Proecerdines of the 1991 IEEE. Pneticte Aecelentor Confor 1991, P 2127.

[3] S.W. Delchaings at al. SSC Collider Dipole Magnet End Mechanieal Desizan ibid, p.2185.

[4] J.S.Brands at al. Coil end Design tor the SSC Collides Dipole Magnet, ibid, p.2182.

[S] C. L. Goodzeit, M D. Anarella, and G. L. Genetion "Measuremear of Internal Eorecs in Supercondueting Accelesabor Magnets with Strain gauge Transduecrs", IERE Trens. Mas. 25, No. 2, 1939, pp 1455-1458.

[6] M. Wake et al. "Mechanical Behevios of Fermilab Genaral Dynamics Built 15-m SSC Collider Magnets". prescuted at the Eourth Asnual Inlernational Industrial Synuposiun on die Supereollider. New Orleans. IA, USA. Mereh 4.6. 1992.

(7) A. Dovrod ot al. "Stutue of 4-em Aperture, 17-m Long SSC Dipole Mognet R\&D Program at BNL, Pat I", SSCCLA8Z 1991.

[8] J. Kuzminski at al. "Test Results of BNL Built 40.mm Aperture, 17-m-Long SSC Collider Dipole Megnets", IEEE Trans. Mag. 28, No. 1, 1992, pp 311.314. 